\title{
Service Quality, Student Satisfaction and Decision in Remaining Active to Study - Study at Private Universities in West Java
}

\author{
Yenny Maya Dora*, Keni Kaniawati, Nina Nurani
}

Widyatama University, Indonesia

Copyright $\mathrm{O} 2019$ by authors, all rights reserved. Authors agree that this article remains permanently open access under the terms of the Creative Commons Attribution License 4.0 International License

\begin{abstract}
In an effort to attract and to retain students, Service Quality, Student Satisfaction and Decision in Remaining Active to Study is an important aspect of the strategy from Private Universities in a competitive higher education market. The purpose of this research is to study the relation among Service Quality, Student Satisfaction and Decision in Remaining Active to Study. Structural Equation Modeling (SEM) is used as a tool of analysis for data of survey result that is conducted to the students of Private Universities in West Java. From the research results of data analysis, it can be seen that Service Quality is very important for Private Universities because Service Quality provided by Private Universities is very influential on Student Satisfaction and Decision in Remaining Active to Study. The findings of this study are useful particularly for decision makers at Private Universities in West Java-Indonesia and generally in Higher Education sector of Indonesia. The improvement in Service Quality can be planned in all Service Quality dimensions, which is a key factor to attract and to retain students.
\end{abstract}

Keywords Decision in Remaining Active to Study, Private Universities, Student Satisfaction, Service Quality

\section{Introduction}

Higher education and higher education institution play a very important role. This is because higher education institution is the development center of intellectual, cultural, social and technology for the society, and it becomes the basis of the leverage in sustainable development.

The condition of higher education environment, especially in private universities, is changing under the influence of social needs, development and transformation of labor market. Currently the competition between Private
Universities is very high, of which students have a variety of options because the options are very diverse. So the factors for universities to attract and to retain students should get more attention. This situation causes private universities to begin implementing the marketing concept in order to survive in the global market of higher education.

The research on Service Quality and Satisfaction has been a major problem in the marketing literature, and it has attracted much attention from the researchers in higher education (Barnes, 2007, Stodnick and Rogers, 2008, Sultan and Wong, 2010, Dado et al, 2011).

According to Lewis (1989) providing high Service Quality is considered as an important determinant of competitiveness and success factors in the service sector and the most powerful competitive weapon for most service organizations (Berry, Parasuraman, and Zeithaml, 1988). DeShields Jr. et al. (2005) propose a strategy that increases student retention through high Service Quality, as high Service Quality increases customer satisfaction, Johns et al (2004).

According to Cronin and Taylor (1992) service providers need to know what their purpose is to have customers satisfied with their services or to provide the maximum Service Quality that will be perceived by the service recipient.

Angell, Heffernan and Megicks, (2008) and Yeo and Li (2012) argue that ignoring the needs and expectations of students and the power of competition in higher education will ultimately lead to losses.

Cuthbert (1996), Owlia and Aspinwall (1996), Clewes (2003), Edden et al (2011), Narang (2012) and Yeo and Li (2012) support the notion of higher education as a service business, as it reveals all the characteristic features of service, it is intangible and inseparable from consumption and higher education meets the heterogeneity and perishable criteria. The approach that regards higher education as a service industry and students as customers has gained considerable support and provided guidance for 
this study.

The research on the relation among Service Quality, Student Satisfaction and Decision in Remaining Active to Study at Private Universities in West Java are still limited. This study is focused on the relation among Service Quality and Student Satisfaction and Decision in Remaining Active to Study which is very important for Private Universities as a service provider.

Private University is one of the higher education institutions that assist the government in realizing its duty to educate the life of the nation. The number of private universities in West Java is more than the number of private universities in other provinces in Indonesia. Based on data from Dikti Porlap, the number of universities in West Java is 58. This makes the competition to get students is very tight among universities in West Java. To maintain its existence, private university is not only getting a lot of students but also maintaining the sustainability of students in studying at the private university that they have chosen.

The purpose of this paper is to know the relation between the Service Quality which is felt by the Students of Private Universities in West Java that make them satisfied and finally they decide to remain active studying.

\section{Literature Review}

The framework of this study is to integrate the knowledge which is gained from previous research and to explore the relation among Service Quality, Student Satisfaction and Decision in Remaining Active to Study.

\subsection{Service Quality}

According to Lewis (1989), Service Quality is considered to be an important dimension of competitiveness, thus becoming an important subject that attracts researchers to conduct research over the past two decades.

The most Service Quality definition which is frequently cited relates to the comparison between the expectation and experience of the service that is received.

According to Parasuraman, Zeithaml, and Berry (1985, 1988), Service Quality is a comparison of what they feel which is offered by service companies with their perceptions to the companies' performance in providing services. So if the customer perception is higher than customer expectation, the quality perceived by the customer will be higher, and vice versa. According to Dedeke (2003), Service Quality is the ability to meet and to exceed the results that providers and customers define and it is defined at the beginning of service meetings, requiring the need to conceptualize the term as a cognitive phenomenon, post-purchase. According to Zeithaml et al (2009); Yildirim, (2018) Service Quality is an evaluation that reflects the customer perception of responsiveness, empathy, assurance, tangibles and reliability.

From the previous description, in this study, the Service Quality which is perceived by the students can be defined as the evaluation of the students to the performance of services which is provided by the university, compared with their expectation level.

\subsection{Student Satisfaction}

According to Mihanović (2007), students are regarded as the main customers among a number of customers and university stakeholders, which means the success or failure of a university is highly dependent on the satisfaction of its students. According to Oliver $(1981,26)$, satisfaction can be described as "a summary of the psychological conditions that are generated when emotions surrounding uncertain expectations are combined with previous consumer feelings about consumption experiences". Sapri et al., (2009) and Ada, et.al (2018) mention that student satisfaction is a short-term attitude resulting from an evaluation of their experience about the educational services that they have received. According to Munteanu et $\mathrm{al},(2010)$, student satisfaction is defined as an evaluative summary of direct education experience, based on the difference between previous expectations and perceived performance after passing through the education cycle.

Service Quality is indicated as the essence to build and to maintain a favorable relationship with the customer and therefore it can be regarded as the antecedent of satisfaction according to (Bigne, Moliner and Sanchez, 2003).

\subsection{Decision in Remaining Active to Study}

According to James F. Engel, Rogerd D. Blackwell, Paul W. Miniard, (1992); Miyaji, (2018) that consumer decisions in choosing a product/ service are influenced by three things: 1) Environmental/ external influences consisting of cultural, social class, family, and situation; 2) Individual/Internal Differences Influences consisting of Consumer Resources (time, money, attention), motivation and involvement, knowledge, attitude, personality, lifestyle, and demography 3) Psychological Influences consisting of processing, information, learning, change attitudes and behavior. Machfoedz (2005) argues that decision-making is a process of appraising and selecting from alternatives according to particular interests by establishing a choice that is considered most favorable. The appraising process usually begins by identifying key issues that influencing the objectives, developing, analyzing, and selecting those alternatives and making the decisions that are considered the best. The final step of the process is the evaluation system to determine the effectiveness of the decisions that are taken.

Schiffman and Kanuk (2007); Okpechi, et.al (2018); Rakab (2018); Dong \& Qiu, (2018) argue that 
decision-making processes as important processes which are influenced by the external environment consisting of marketing mix (product, promotion, price, distribution) and socio-cultural environment (family, information source, non-commercial source, social class, culture and sub-cultures), then the internal environment (psychological factors) consisting of motivation, personality, learning, perception, and attitude. Terry (2008), decision-making is an alternative selection behavior of two or more alternatives. Griffin (2012); Vargas (2017), decision making is the act of choosing an alternative from a series of alternatives.

From the opinion of the researchers above the concept of Decision in Remaining Active to Study for this study is the student action to choose an alternative of two or more alternatives based on the appraising results that is influenced by external and internal environmental conditions.

\section{Framework and Hypotheses}

\subsection{Framework}

Based on the theoretical framework which is described above, it is developed a framework for this study that can be seen in Figure 1.

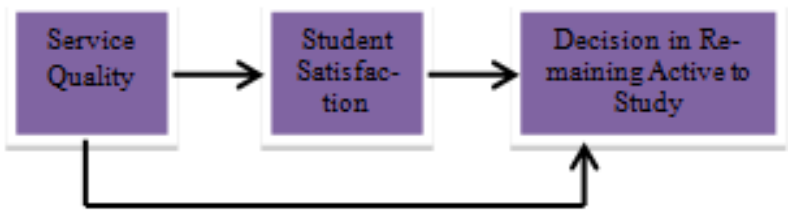

Source: Processed Data, 2018

\section{Figure 1. Framework}

Based on the framework in Figure 3.1, the hypothesis for this study is as follows:

1. $\mathrm{H}_{1}$ : There is an influence between Service Quality to Student Satisfaction.

2. $\mathrm{H}_{2}$ : There is an influence between Service Quality to Decision in Remaining Active to Study.

3. $\mathrm{H}_{3}$ : There is an influence between Student Satisfaction to Decision in Remaining Active to Study.

\section{Research Methodology}

This study is a descriptive research that investigates the influence on Service Quality, Student Satisfaction and Decision in Remaining Active to Study.

The research variables can be grouped into two: first, exogenous variable (independent) is Service Quality $\left(\mathrm{X}_{1}\right)$ Second, endogenous variable consisting of satisfaction $\left(\mathrm{Y}_{1}\right)$ and Decision in Remaining Active to Study $\left(\mathrm{Y}_{2}\right)$ (dependent variable).

The study is conducted on Private University students in West Java who have attended the lecture $\geq 3$ Semesters. With a total population of 224,542 students in the 2016 academic year, using a slovin formula with $5 \%$ clearance, the number of samples for this study is 340 students. And the method of sampling is with certain criterion (purposive sampling) and it is sampling which is conducted by taking selected people according to the specific characteristic which is possessed by the sample. Researchers use purposive samples because researchers use the students with certain criteria to be sampled. The criteria are the students who are minimum in semester $\geq 3^{\text {rd }}$.

For analysis of data which is collected, it uses AMOS structural equation model (SEM).

\section{Results and Discussion of Research}

\subsection{Research Result}

\subsubsection{Instrument Test Results}

Validity Test Results

The following are validity test results for the questionnaire to variable of Service Quality, Student Satisfaction and Decisions in Remaining Active to Study on table 1 below:

Tabel. 1. Validity test results of Service Quality, Student Satisfaction and Decisions in Remaining Active to Study

\begin{tabular}{|c|c|c|c|}
\hline Item & $\begin{array}{c}\text { Corrected Item- } \\
\text { Total Correlation }\end{array}$ & r-tabel & Status \\
\hline KP1 & 0,589 & 0,264 & Valid \\
\hline KP 2 & 0,622 & 0,264 & Valid \\
\hline KP 3 & 0,687 & 0,264 & Valid \\
\hline KP 4 & 0,678 & 0,264 & Valid \\
\hline KP 5 & 0,701 & 0,264 & Valid \\
\hline KM 1 & 0,692 & 0,264 & Valid \\
\hline KM 2 & 0,715 & 0,264 & Valid \\
\hline KM 3 & 0,736 & 0,264 & Valid \\
\hline KTAK 1 & 0,637 & 0,264 & Valid \\
\hline KTAK 2 & 0,652 & 0,264 & Valid \\
\hline KTAK 3 & 0,623 & 0,264 & Valid \\
\hline KTAK 4 & 0,677 & 0,264 & Valid \\
\hline KTAK 5 & 0,701 & 0,264 & Valid \\
\hline KTAK 6 & 0,682 & 0,264 & Valid \\
\hline
\end{tabular}

Source: Processed primary data, 2018

Based on table 1, it can be seen that all questions for Service Quality, Student Satisfaction and Decision in Remaining Active to Study have valid status, because the value of corrected item-total correlation is $>0.264$. 


\section{Reliability Test}

The instrument reliability coefficient is intended to see the consistency of answers to the statement items that are given by the respondents. The analytical tool uses the method of split half to correlate the total odd versus even score, and then the reliability is calculated using the alpha cronbach formula. The following is the reliability test results for this research instrument in table 2 .

Table 2. The result of the reliability of Service Quality, Student Satisfaction and Decision in Remaining Active to Study

\begin{tabular}{|c|c|c|c|c|}
\hline No & Variabel & Ralpha & rCritis & Status \\
\hline 1 & Service Quality & 0,789 & 0,600 & Reliabel \\
\hline 2 & Student Satisfaction & 0,816 & 0,600 & Reliabel \\
\hline 3 & $\begin{array}{c}\text { Decision in Remaining } \\
\text { Active to Study }\end{array}$ & 0,815 & 0,600 & Reliabel \\
\hline
\end{tabular}

Source: Processed primary data, 2018

From Table 2 the result of the reliability coefficient to the instrument of Service Quality, Student Satisfaction and Decision in Remaining Active to Study has an alpha cronbach value which is greater than 0.600 , which means the three instruments are declared reliable or meet the requirements.

\subsubsection{Data Analysis Results}

\section{Structural Equation Modeling (SEM) Analysis}

The data analysis result by using Structural Equation Modeling or SEM is presented in table 3.

\subsubsection{Data Analysis Results}

\section{Structural Equation Modeling (SEM) Analysis}

The data analysis result by using Structural Equation Modeling or SEM is presented in table 3.

Table 3. Feasibility Test Result of Structural Equation Model (SEM) Model

\begin{tabular}{|c|c|c|c|}
\hline Criteria & Cut-Off-Value & $\begin{array}{c}\text { Analysis } \\
\text { Result }\end{array}$ & $\begin{array}{c}\text { Model } \\
\text { Evaluation }\end{array}$ \\
\hline $\begin{array}{c}\alpha^{2} \\
(\text { Chi-Square })\end{array}$ & Expected Small & 118.986 & Good \\
\hline Probability & $\geq 0.05$ & 0.266 & Good \\
\hline RMSEA & $\leq 0.08$ & 0.019 & Good \\
\hline CMIN/DF & $\geq 2.00$ & 1.048 & Good \\
\hline GFI & $\geq 0.90$ & 0.917 & Good \\
\hline AGFI & $\geq 0.91$ & 0.986 & Good \\
\hline TLI & $\geq 0.95$ & 0.893 & Marginal \\
\hline CFI & $\geq 0.95$ & 0.997 & Good \\
\hline
\end{tabular}

Source: Processed primary data, 2018

These results indicate that the model which is used is acceptable. The AGFI, CFI, CMIN/DF and RMSEA measurements index are within the expected range of values even though TLI is received marginally. Thus the feasibility test of the SEM model has met the acceptance requirement.

Evaluation of normality is done by using criteria of critical ratio skewness value and kurtosis value, of which the value of both ratio that have value less than absolute value of 2.58 means the data is in normal distribution. From the results of data processing that are seen in Table 3 shows that there is no value of C.R. for skewness that is outside the range \pm 2.58 . Thus, the research data which is used has met the requirements of data normality, or it can be said that the research data has been normally distributed.

\section{Evaluation of Multicollinearity and Singularity}

The next data testing is to see whether there is multicolinearity and singularity in a combination of variables. Indication of multicolinearity and singularity can be known through the determinant value of the covariance matrix which is really small, or close to zero. From data processing result, the value of sample covariance matrix determinant is determinant of sample covariance matrix $=$ $0.005>0$.

From data processing results, it can be known that determinant of sample covariance matrix value is far from zero. Thus it can be said that there is no multicolinearity and singularity in the research data which is used.

\section{Hypothesis Testing}

After all assumptions can be met, it will be tested hypothesis. The results of hypothesis testing are presented in table 4

Tabel 4. Regression Weight Structural Equational Model

\begin{tabular}{|c|c|c|c|c|}
\hline $\begin{array}{c}\text { Hubungan antar } \\
\text { Variabel }\end{array}$ & Estimate & S.E. & C.R. & P-val \\
\hline $\begin{array}{c}\mathrm{KP}(\mathrm{X} 1)==>\mathrm{KM} \\
(\mathrm{Y} 1)\end{array}$ & 0,411 & 0,107 & 2,968 & 0,003 \\
\hline $\begin{array}{c}\mathrm{KP}(\mathrm{X} 1)==>\mathrm{KTAK} \\
(\mathrm{Y} 2)\end{array}$ & 0,453 & 0,104 & 3,566 & 0,000 \\
\hline $\begin{array}{c}\mathrm{KM}(\mathrm{Y} 1)==>\mathrm{KTAK} \\
(\mathrm{Y} 2)\end{array}$ & 0,498 & 0,099 & 5,487 & 0,000 \\
\hline
\end{tabular}

Source: Processed primary data, 2018

From the testing results in table 4 , it is found that all CR values are above 1.96 or with probabilities that are smaller than 0.05 . Thus all hypotheses are accepted.

\subsection{Discussion}

The results of this study clarify that the Service Quality is instrumental in creating student satisfaction and further form the decision of students to remain active studying. The results of this study are in accordance with the research of Hanaysah et al, (2012), Saif (2014) and Meštrović (2017). The most significant and influential indicators of Service Quality are the learning support facilities, the attitudes and abilities of the teachers, and the good interaction of administrative staff with students. These indicators have an influence on student satisfaction. The learning support facilities provided by the university 
should be able to function well at the time of learning takes place. The learning facilities include: classrooms, Infokus, Whiteboard, Markers, and Wifi.

While the most influential Service Quality indicators to the decision in remaining active to study are the attitude and ability of the teachers, where the attitude of the lecturers to the students is very influential on the comfort, tranquility and confidence of students will be treated well and fair during the education. So that during lectures the teachers should be able to be wise and fair to the attitude and behavior of students, and should not be subjective in treating and giving assessment to students. In addition, students also feel confident with the ability of teachers who teach them to be seen from the way the teachers teach, give examples, directions, tasks and discussions conducted during the lecture. And the ability of the staff is related to the timeliness of service, speed and accuracy in providing services to students.

Meanwhile, the indicator of student satisfaction that influences the decision in remaining active to study is the performance of lecturers and staff. Students assess the performance of lecturers during the lecture related to the timeliness present in the class, the suitability of the lecture material to be provided with the syllabus, the lecturer present in accordance with the number of attendance that has been determined and submit the value in accordance with the time specified. For the performance of university staff on time attendance to serve the students, accuracy in conveying information and announcements, the suitability of services provided with the required by the students and the accuracy in providing information about the value of students.

\section{Conclusions}

The purpose of this study is to determine the relation between Service Quality that is perceived by Private University Students in West Java that make them satisfied and finally decided to remain active studying. From the data results, it can be concluded that Service Quality influences Student Satisfaction and Decision in Remaining Active to Study [19]. This proves that Service Quality is a key factor for Student Satisfaction and Decision in Remaining Active to Study. Meanwhile, Student Satisfaction also influences Decision in Remaining Active to Study which impacts to the decision. It means making students satisfied is very important because it will have an impact on maintaining the continuity of student studies. Therefore, the leaders of the Private Universities are expected to evaluate the Service Quality that has been given and to make improvements and to develop new strategies in improving Service Quality that will impact on increasing Student Satisfaction and Student Decision in remaining active to study.

\section{Acknowledgements}

I would like to thank: 1. Ministry of Research, Technology and Higher education of The Republic of Indonesia who has funded my research. 2. Rector, Vice Rector, Dean of Faculty of Business and Management of University Widyatama who support me in doing this research. 3. All leaders of private universities in West Java who helped me in collecting data. 4. Fellow lecturers and students who always help me in collecting and processing this research data.

\section{REFERENCES}

[1] Angell, R.J.; Heffernan, T.W. and Megicks, P.: Service Quality in Postgraduate Education. Quality Assurance in Education 16(3), 236-254, 2008.

[2] Athiyaman, A.: Linking student satisfaction and service quality perceptions: the case of university education. European Journal of Marketing 31(7), 528-540, 1997.

[3] Cronin, J.J. and Taylor, S.A.: Measuring Service Quality: A Re-examination and Extension. Journal of Marketing 56(3), 55-68, 1992.

[4] Cuthbert, P.F.: Managing Service Quality in HE: Is SERVQUAL the Answer? Part 1. Managing Service Quality 6(2), 11-16, 1996.

[5] Dado, J.; Taborecka-Petrovičova, J.; Riznić, D. and Rajić, T.: An Empirical Investigation into the Construct of Higher Education Service Quality. International Review of Management and Marketing 1(3), 30-42, 2011.

[6] Dedeke, A.: Service Quality: A fulfillment-oriented and interactions-centred approach. Managing Service Quality 13(4), 276-289, 2003.

[7] DeShields Jr., O.W.; Kara, A. and Kaynak, E.: Determinants of Business Student Satisfaction and Retention in Higher Education: Applying Herzberg's Two-Factor Theory. International Journal of Educational Management 19(2), 128-139, 2005.

[8] Dunja Meštrović, Service Quality, Students' Satisfaction And Behavioural Intentions In Stem And IC Higher Education Institutions", Interdisciplinary Description of Complex System 15(1), 66-77, 2017.

[9] Engel, James F, Blackwell, Rogre D and Miniard, Paul W, (1994), Perilaku Konsumen, Jilid-1, Binaputra Aksara, Jakarta.

[10] Dong, T., \& Qiu, L. Research on Self-Mentions and Author Identity in Academic English Writing. International Journal of English Language and Literature Studies, 7(4), 115-121, 2018 .

[11] Grönroos, C.: Strategic management and marketing in the service sector. Marketing Science Institute, Cambridge, 1982.

[12] Jalal R. M. Hanaysha, Dileep Kumar, Othman Yoep 
Abdullah, Hilman H, Service Quality and Satisfaction: Study In International Students In Universities of North Malaysia", International Journal of Research In Management, Vol.3,pg 116-133, 2012.

[13] Rakab, M. B. The Frequency Effects of a Relatively Rarely Used Grammar Structure: The Case of Had Better. International Journal of English Language and Literature Studies, 7(4), 101-114, 2018.

[14] Mihanović, Z.: The role of customers in higher education: Are students active stakeholders? Market-Trziste 19(1), 115-132, 2007.

[15] Narang, R.: How do Management Students Perceive the Quality of Education in Public Institutions? Quality Assurance in Education 20(4), 357-371, 2012.

[16] Parasuraman, A., Berry, L.L. and Zeithmal, V.A. 1985. A Conceptual Model of Service Quality and Its Implication for Future Research, Journal of Marketing, Vol. 49, pg. 41.

[17] Parasuraman, A.; Zeithaml, V. and Berry, L.: SERVQUAL: A Multiple-Item Scale for Measuring Consumer Perceptions of Service Quality. Journal of Retailing 64(1), 12-40, 1988.

[18] Shiffman, Leon G and Kanuk, Leslie, Laser, 2007, Perilaku Konsumen, Edisi ketujuh, Indeks, Jakarta.

[19] Esmaeilpour, M., \& Hoseini, M. (2017). Explaining the impact of service quality on identity and brand personality. Polish Journal of Management Studies, 16 (2), 88-98.

[20] Miyaji, I. (2018). Comparison of Useful Activities of Improving Awareness in Blended Classes in Java Script and PHP Programming. International Journal of Educational Technology and Learning, 3(2), 78-92.

[21] Ada, E. N., Cetinkalp, Z. K., Altiparmak, M. E., \& Asci, F. H. (2018). Flow Experiences in Physical Education Classes: The Role of Perceived Motivational Climate and Situational Motivation. Asian Journal of Education and Training, 4(2), $114-120$

[22] Yildirim, S. (2018). The Effect of Educational Videos Used in History Education on Academic Success. Journal of Education and e-Learning Research, 5(3), 193-207.

[23] Vargas, M. A. P. (2017). Academic Procrastination: The Case of Mexican Researchers in Psychology. American Journal of Education and Learning, 2(2), 103-120.

[24] Okpechi, P. A., Denwigwe, C. P., Asuquo, P. N., Abuo, C., \& Unimna, F. U. (2018). Awareness and Utilization of e-Learning Resources by Trainee Counsellors of Counselling Education in Calabar, Nigeria. International Journal of Educational Technology and Learning, 3(2), 45-51. 